\title{
Ethno-botanical Knowledge on Diversity of Cucurbita Landraces Grown in Northern KwaZulu-Natal, South Africa
}

\author{
Nontuthuko R. Ntuli' ${ }^{1, *}$, Rufaro M. Madakadze², Alpheus M. Zobolo ${ }^{1}$ \\ ${ }^{1}$ Department of Botany, University of Zululand, South Africa \\ ${ }^{2}$ African Crop Improvement Alliance for a Green Revolution in Africa, Kenya
}

Copyright $\bigcirc 2016$ by authors, all rights reserved. Authors agree that this article remains permanently open access under the terms of the Creative Commons Attribution License 4.0 International License

\begin{abstract}
Ethnobotanical knowledge on local Cucurbita landraces was documented in three district municipalities of northern KwaZulu-Natal, South Africa. Seven distinct landraces of C. argyrosperma, C. maxima and C. pepo were identified by local (isiZulu) names as iNhlwathi emhlophe, iNhlwathi emnyama, iPhuzi, isiPhama, iThanga, uMpampini oluhlaza and uMpampini ophuzi. The majority had leaves with silvery-white mottling in axils of leaf veins, but isiPhama and uMpampini oluhlaza had uniformly green leaves. INhlwathi emhlophe and iNhlwathi emnyama had the largest fruits and isiPhama had the smallest. Landrace iNhlwathi emnyama maintained its green fruit colour at maturity, while iPhuzi changed to uniform yellow/orange fruit colour before maturity. The isiPhama, uMpampini oluhlaza and uMpampini ophuzi had sparse to moderate stem branching habit and the sweetest, less watery fruits of them all. Seed colour ranged from cream to white. This study was the first attempt to record the genetic-related diversity on types of Cucurbita landraces that are grown in South Africa. It also recorded the presence of $C$. argyrosperma for the first time in this country.
\end{abstract}

Keywords Cucurbita Landraces, Indigenous Knowledge, Traditional Leafy Vegetables

\section{Introduction}

Pumpkins, represented by various Cucurbita species, are nutritionally and economically important [1]. Their mature and young fruits, seeds, staminate flowers, leaves and young shoot tips are consumed as leafy vegetables [2, 3]. Cucurbita species are important sources of vitamin $\mathrm{C}$, minerals and $\beta$-carotene [4]. The genus Cucurbita is of American origin and is distributed from United States to Argentina [4, 5]. Of the five domesticated Cucurbita species: C. pepo; C. maxima;
C. moschata; C. argyrosperma (mixta) and C. ficilifolia [1], the former three species are the most cultivated species [5]. In South Africa Cucurbita pepo landraces are widely grown and used as a traditional leafy vegetable [6].

A landrace is an early cultivated form of a crop species, evolved from a wild population, and generally composed of a heterogeneous mixture of genotypes [7]. It is also known as traditional and local crop variety particularly used by local farmers [8]. Landraces are the important genetic resources for plant breeders because of their considerable genotypic variation [9].

Cucurbita species vary widely morphologically, genetically and agro-ecologically, where the latter includes tropical and subtropical regions, arid deserts and temperate locations [10]. Their growth habit varies between vine type with vine lengths reaching about $15 \mathrm{~m}$ and bush type with shorter vines [5, 11]. Leaves of Cucurbita landraces have wide diversity in their size, shape, colour, hairiness and texture [12]. Flowers of Cucurbita landraces vary widely in their colour, size and shape [10]. Extreme diversity is found in shape, size and colour of fruits and seeds among Cucurbita species [3, 9].

Limited study on collection and conservation of $C$. maxima and $C$. pepo accessions was initiated in KwaZulu-Natal midlands and Limpopo provinces of South Africa [13]. No work to date has recorded the Cucurbita landraces that are grown by smallholder farmers and collected the available knowledge on these vegetables, in northern KwaZulu-Natal province, South Africa. Identification and characterization of diversity in landraces provide breeders with considerable amount of information concerning their value to particular breeding programs. Breeders may then exploit these genetic resources in several ways to produce new cultivars. The objectives of this study were to identify different Cucurbita landraces that are grown and to document ethno-botanic knowledge on their characterization in three district municipalities of northern KwaZulu-Natal. 


\section{Materials and Methods}

The survey was conducted in Umkhanyakude (Mseleni: $27^{\circ} 38^{\prime} \mathrm{S}, 32^{\circ} 47^{\prime} \mathrm{E}$ ), uThungulu (Nkandla: $28^{\circ} 37^{\prime} \mathrm{S}, 31^{\circ}$ $25^{\prime} \mathrm{E}$ ) and Zululand (Ulundi: $28^{\circ} 32^{\prime} \mathrm{S}, 31^{\circ} 47^{\prime} \mathrm{E}$ ) district municipalities of northern KwaZulu-Natal. The interviews through structured questionnaires were conducted in isiZulu in a total of 450 households. In each district, three villages were chosen where fifty households per village were interviewed. To consolidate the information obtained from household interviews, focus groups of three to ten people per group were interviewed using garden and general community meetings.

Interviewees listed different types of Cucurbita landraces and characterized them according to their stem (hairiness and branching habit), leaf (mottling and hairiness), fruit (speckling, size, shape and internal hollowness) and seed (shape and colour); and also recorded the part(s) used for vegetable purposes. Additional information such as derivation of landrace name, fruit sweetness and water content was recorded as per interviewees' note. Ten plants per each landraces were studied to confirm the interviewees' reports especially on plant morphological features.

Voucher specimens were collected concurrently with interviews. However, in cases where only seeds were available with the communities, they were grown at the University of Zululand Ethno-Botanic Garden for the preparation of voucher specimens as according to Fish [14].

\section{Results}

Seven distinct Cucurbita landraces were identified in the surveyed areas (Table 1). The incidence of occurrence and/or knowledge as determined by the number of specimens studied per landraces per district is also indicated in this table. These landraces belonged to the following Cucurbita species: C. argyrosperma (isiPhama); C. maxima (uMpampini oluhlaza); C. maxima/pepo (uMpampini ophuzi); and C. pepo (iNhlwathi emhlophe, iNhlwathi emnyama, iPhuzi and iThanga). Their names were derived mainly from mature fruit colour and variegation. However, the meanings of isiPhama and iThanga landraces were uncertain. When excluding uMpampini ophuzi landrace, the $C$. pepo had the highest number (four) of landraces. The iThanga and uMpampini oluhlaza landraces were known in all districts. The isiPhama, iNhlwathi emnyama and iNhlwathi emhlophe landraces were known only at Umkhanyakude district; iPhuzi at Zululand district; and uMpampini ophuzi only at uThungulu district. UMpampini oluhlaza landrace is also known as $u Z u l u$ and $u$ Gubung $u$ at uThungulu and Zululand districts. The majority of Cucurbita landraces had profuse stem branching habit except isiPhama, uMpampini ophuzi and uMpampini oluhlaza landraces. Leaves of only isiPhama and uMpampini oluhlaza landraces were uniformly green with soft hairs but other landraces had green and silvery-white mottling leaves with tough prickly hairs (Table 1; Figure 1).

Fruit shape and size varied widely in all landraces, except the fixed small sizes of isiPhama and uMpampini ophuzi landraces. Cucurbita pepo landraces had significant differences in their mature fruit colour (Table 1; Figure 1). INhlwathi emnyama landrace maintained its deep green or deep green speckled light green at maturity, while $i P h u z i$ landrace changed to pure yellow/orange before the hardening of fruit rind. Only isiPhama landrace had white-coloured seeds, and only uMpampini oluhlaza landrace had ovoid, bulged seed shape. Fruits of most Cucurbita landraces were hollow inside. However, fruits of isiPhama and uMpampini oluhlaza landraces were completely filled internally, whereas fruits of uMpampini ophuzi were intermediate.

UMpampini ophuzi landrace had distinct features of both C. maxima (fruit shape) and C. pepo (stem spines; leaf mottling and hairiness; fruit speckling; seed shape and colour). However, its stem branching habit and fruit internal hollowness was intermediate.

Communities of northern KwaZulu-Natal consume leafy shoot tips, flowers, young and mature fruits, and seeds of Cucurbita landraces. The shoot tips of many landraces were picked for vegetable consumption until senescence, except uMpampini oluhlaza landraces which developed a bitter taste with age. Therefore their consumption was enjoyed at their early stages of growth and particularly during famine. Nevertheless, cooked fruits of isiPhama, uMpampini oluhlaza and uMpampini ophuzi landraces were the sweetest and less watery, thus were most preferred. However, they had a limitation of very low fruit yield. 
Table 1. Cucurbita landraces with qualitative stem, leaf, fruit and seed characters generated from the survey ( $\mathrm{n}=450)$

\begin{tabular}{|c|c|c|c|c|c|c|}
\hline Landrace name & $\begin{array}{l}\text { Scientific } \\
\text { name }\end{array}$ & Voucher & $\begin{array}{c}\text { District(s) } \\
\text { (specimen } \\
\text { studied) }\end{array}$ & Stems & Leaves & $\begin{array}{c}\text { Fruits, seeds and taste (sweetness } \\
\text { and texture) }\end{array}$ \\
\hline iNhlwathi emhlophe & C. pepo & NRN 510 & M (13) & $\begin{array}{l}\text { Tough prickly } \\
\text { spines; profuse } \\
\text { branching habit }\end{array}$ & $\begin{array}{l}\text { Green mottled } \\
\text { silvery-white on } \\
\text { veins; tough } \\
\text { prickly hairs }\end{array}$ & $\begin{array}{c}\text { Very large round, ovoid and } \\
\text { oblong, yellow/orange speckled } \\
\text { white at maturity, hollow inside. } \\
\text { Flattened cream seeds. Sweet } \\
\text { and watery cooked fruits. }\end{array}$ \\
\hline iNhlwathi emnyama & C. pepo & NRN 511 & M (10) & $\begin{array}{l}\text { Tough prickly } \\
\text { spines; profuse } \\
\text { branching habit }\end{array}$ & $\begin{array}{l}\text { Green mottled } \\
\text { silvery-white on } \\
\text { veins; tough } \\
\text { prickly hairs }\end{array}$ & $\begin{array}{l}\text { Very large round, ovoid and } \\
\text { oblong, either deep green or dark } \\
\text { green speckled light green up to } \\
\text { maturity, hollow inside. } \\
\text { Flattened cream seeds. Sweet } \\
\text { and less watery cooked fruits. }\end{array}$ \\
\hline iPhuzi & C. pepo & NRN 513 & $Z(150)$ & $\begin{array}{l}\text { Tough prickly } \\
\text { spines; profuse } \\
\text { branching habit }\end{array}$ & $\begin{array}{l}\text { Green mottled } \\
\text { silvery-white on } \\
\text { veins; tough } \\
\text { prickly hairs }\end{array}$ & $\begin{array}{l}\text { Large to very large, round, ovoid } \\
\text { and oblong, light green speckled } \\
\text { white at a very tender stage but } \\
\text { change to full yellow/orange } \\
\text { before reaching maturity, hollow } \\
\text { inside. Flattened cream seeds. } \\
\text { Tasteless to mild sweet and } \\
\text { watery cooked fruits. }\end{array}$ \\
\hline isiPhama & $\begin{array}{c}C . \\
\text { argyrosperma }\end{array}$ & NRN 507 & M (4) & $\begin{array}{l}\text { Soft whitish } \\
\text { spines (hairs); } \\
\text { sparse branching } \\
\text { tendency }\end{array}$ & $\begin{array}{l}\text { Green, with soft } \\
\text { hairs. }\end{array}$ & $\begin{array}{l}\text { Small, round to ovoid, } \\
\text { grayish-green, filled inside. Thin } \\
\text { edible rind. Flattened white } \\
\text { seeds. Very sweet and less } \\
\text { watery cooked fruits. }\end{array}$ \\
\hline iThanga & C. pepo & NRN 353 & $\begin{array}{c}\mathrm{M}(150), \\
\mathrm{T}(150), \\
\mathrm{Z}(150)\end{array}$ & $\begin{array}{l}\text { Tough prickly } \\
\text { spines; profuse } \\
\text { branching habit }\end{array}$ & $\begin{array}{l}\text { Green mottled } \\
\text { silvery-white on } \\
\text { veins; tough } \\
\text { prickly hairs }\end{array}$ & $\begin{array}{c}\text { Small to large round, ovoid and } \\
\text { oblong, yellow/orange speckled } \\
\text { white at maturity, hollow inside. } \\
\text { Flattened cream seeds. Tasteless } \\
\text { to mild sweet and watery cooked } \\
\text { fruits. }\end{array}$ \\
\hline uMpampini oluhlaza & C. maxima & NRN 508 & $\begin{array}{c}\mathrm{M}(7), \mathrm{T} \\
(18), \mathrm{Z}(26)\end{array}$ & $\begin{array}{l}\text { Soft hairs when } \\
\text { plant is young } \\
\text { but become } \\
\text { tough and prickly } \\
\text { with age; sparse } \\
\text { to moderate } \\
\text { branching habit }\end{array}$ & $\begin{array}{l}\text { Green, with soft } \\
\text { to moderately } \\
\text { tough hairs. }\end{array}$ & $\begin{array}{l}\text { Large, flattened to round, ribbed, } \\
\text { grayish-green, filled inside. } \\
\text { Ovoid, bulged cream seeds, with } \\
\text { a peeling outer cover. Very sweet } \\
\text { and less watery cooked fruits. }\end{array}$ \\
\hline uMpampini ophuzi & $\begin{array}{c}C . \\
\text { maxima/pepo }\end{array}$ & NRN 512 & $\mathrm{~T}(6)$ & $\begin{array}{l}\text { Tough prickly } \\
\text { spines; sparse to } \\
\text { moderate } \\
\text { branching habit }\end{array}$ & $\begin{array}{l}\text { Green mottled } \\
\text { silvery-white on } \\
\text { veins; tough } \\
\text { prickly hairs }\end{array}$ & $\begin{array}{c}\text { Small, flattened to round, ribbed, } \\
\text { yellow/orange speckled white, } \\
\text { partly filled inside. Flattened } \\
\text { cream seeds. Very sweet and less } \\
\text { watery cooked fruits. }\end{array}$ \\
\hline
\end{tabular}

Landrace names are in isiZulu. Voucher: NRN, NR Ntuli. Districts: M, Umkhanyakude; T, uThungulu; Z, Zululand.

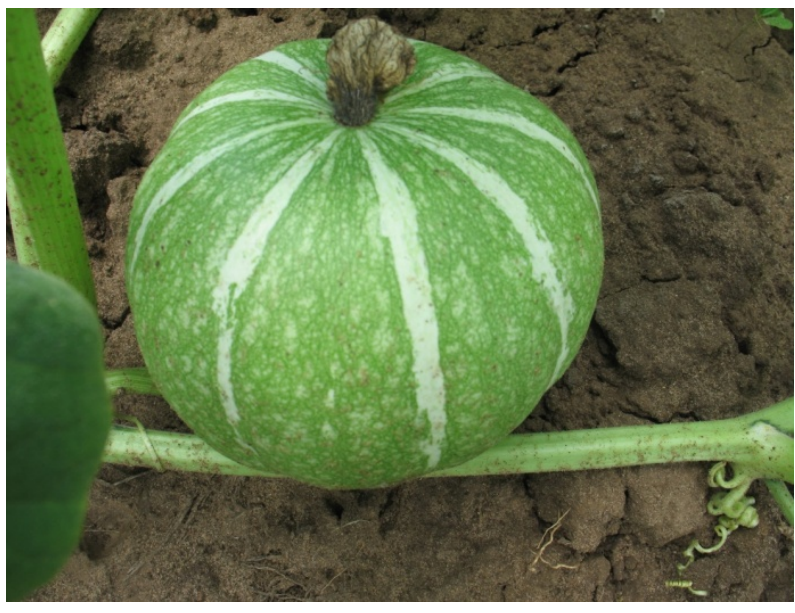

A

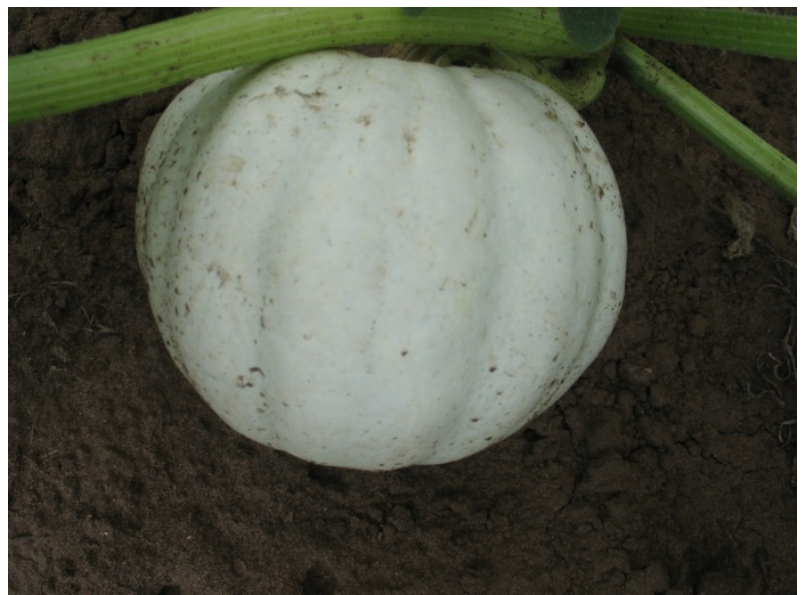




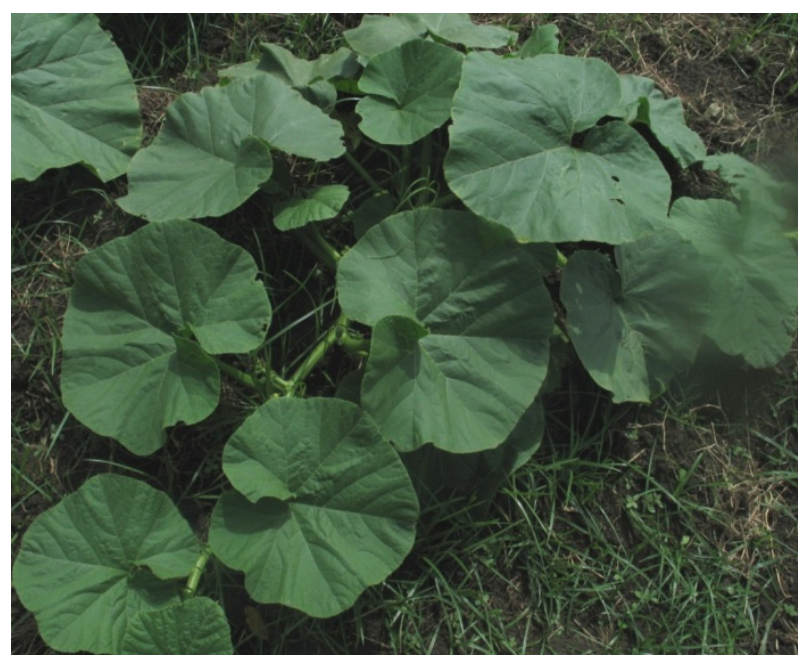

C

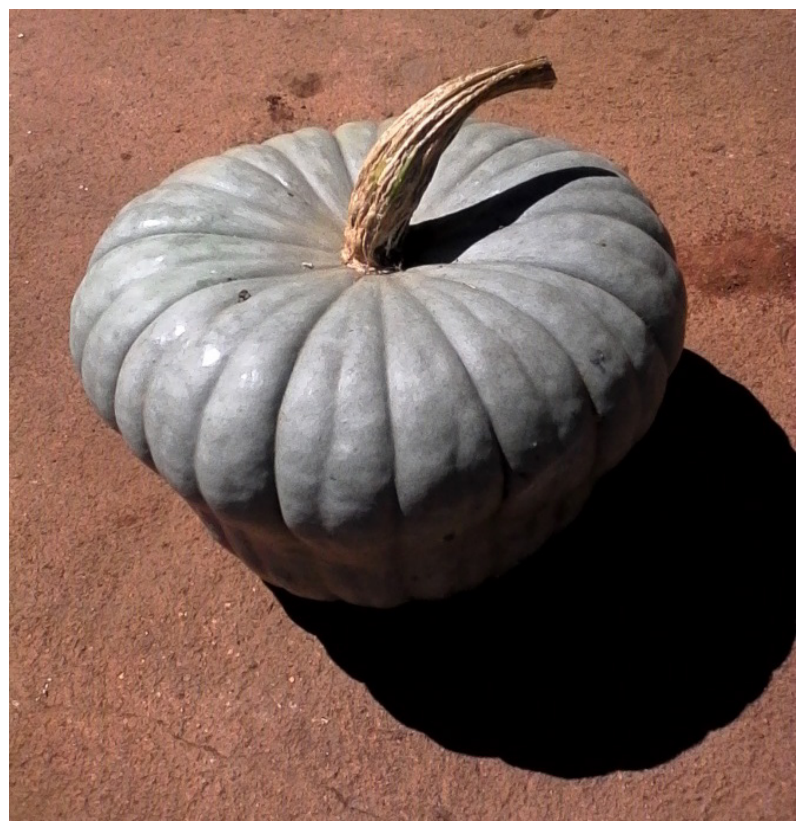

D

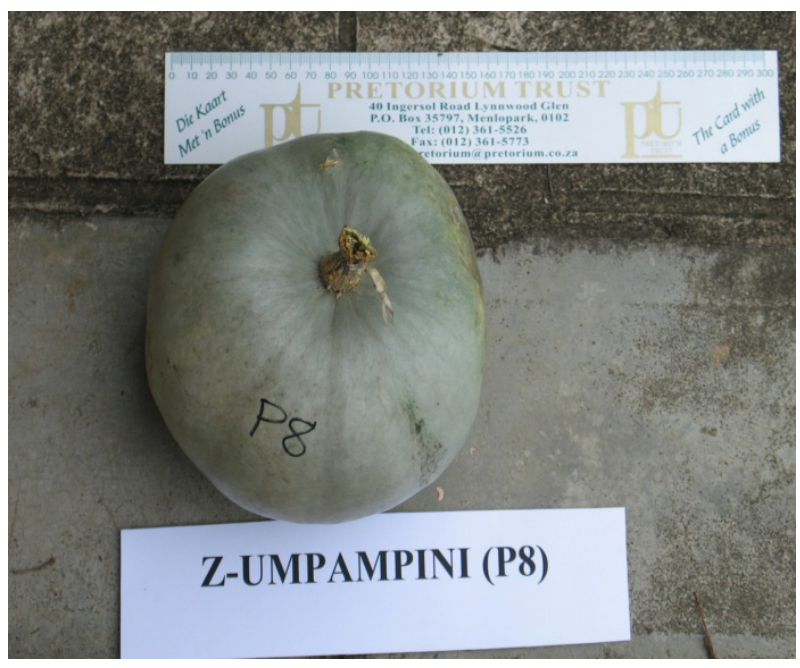

E

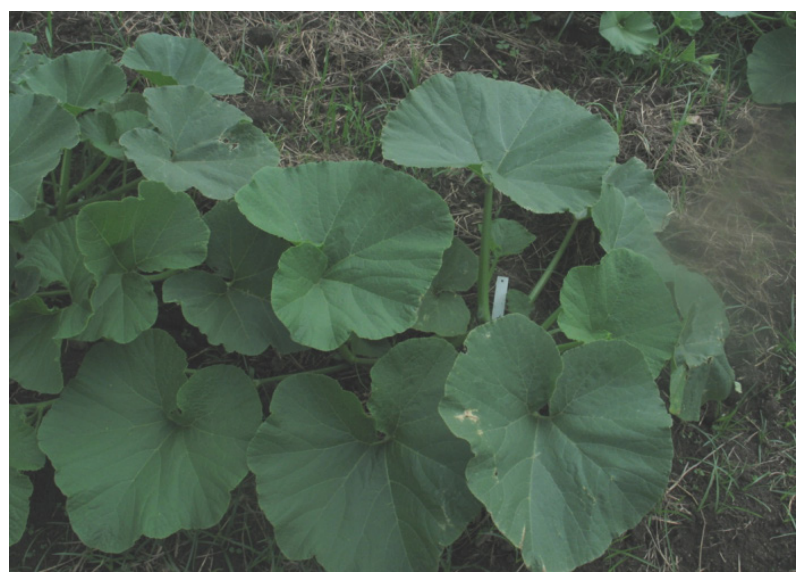

F

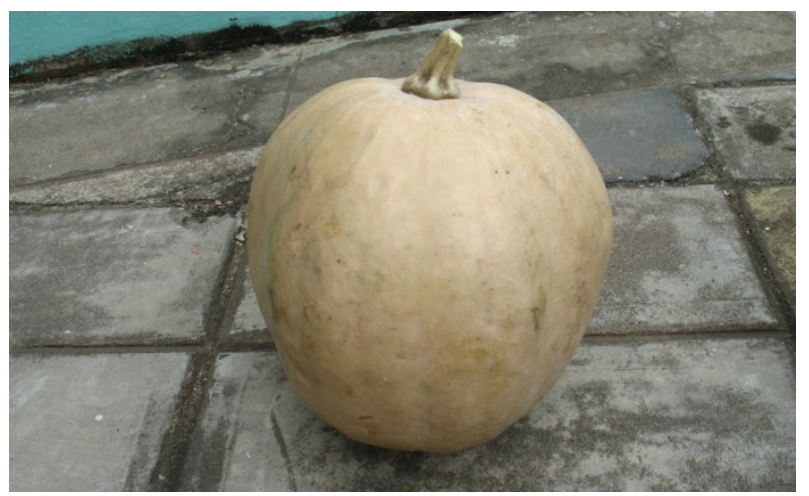

G

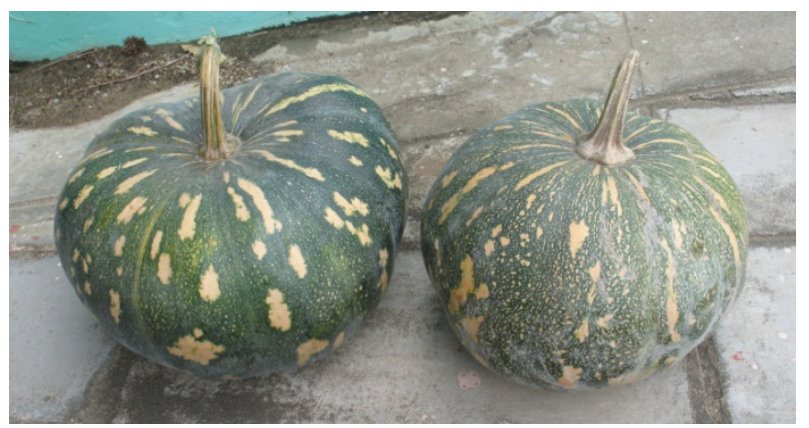

$\mathrm{H}$

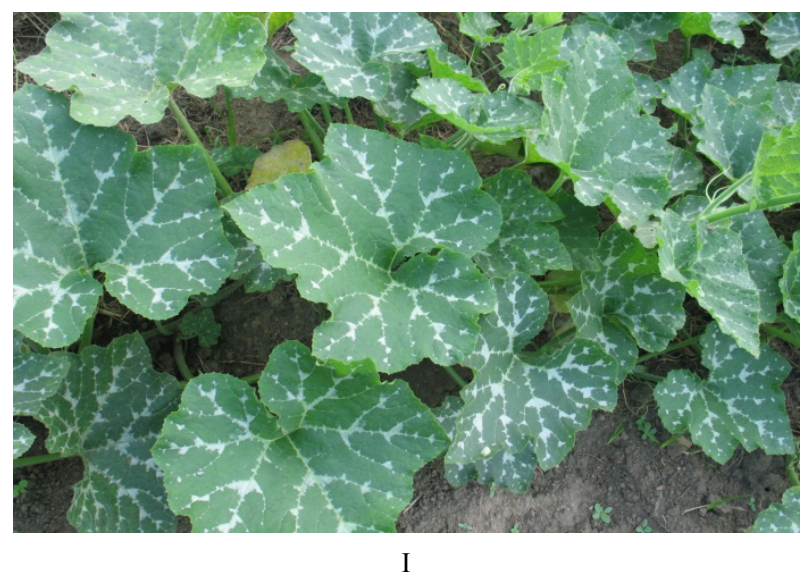

Figure 1. Fruits and shoots of C. argyrosperma (A, B \& C); C. maxima (D, $\mathrm{E} \& \mathrm{~F})$ and $C$. pepo (G, H \& I) landraces. 


\section{Discussion}

Seven landraces of $C$. agryrosperma, C. maxima and $C$. pepo species whose names were derived from mature fruit colour and variegation, were identified in northern KwaZulu-Natal. In Manicaland province, Zimbabwe, seven identified C. maxima-moschata landraces' names were coined from the leaf and fruit colour ("Nzunzu"), fruit size ("Ditimanga"), taste of the fruit ("Ndodo") and from rind thickness ("Hokore") [12].

Countries such as Bangladesh [15], Egypt [1], Nigeria [10], and Turkey [9, 16], have different numbers of Cucurbita species accessions. However, in South Africa the Agricultural Research Council genebank in Roodeplaat, has a total of $36 C$. pepo and $C$. maxima accessions that were only collected from Bushbuckridge, Polokwane and Ladysmith areas [13]. Therefore documentation of indigenous knowledge, confirmation of the supplied indigenous information through agronomic and molecular characterization, and conservation of these landraces is essential for Cucurbita breeding, improvement and increase in accessions (genetic diversity) in South Africa.

Former research on cultivated Cucurbita species in South Africa focused only on C. maxima, C. moschata and C. pepo $[2,13,17,18]$, but have not included $C$. argyrosperma. This might be caused by limited cultivation of $C$. argyrosperma in this country, as it was known by few individuals of Mbazwana and Mseleni villages at Umkhanyakude district only. It could also result from this landrace becoming extinct from all parts of South Africa and is rarely grown by communities; as in accordance with the study of $C$. pepo landraces in Jordan [19]. Therefore its conservation and improvement is essential.

Stem branching habit ranged from sparse through moderate to profuse, which is associated with bush, intermediate and vining growth habits, respectively. This stem branching and growth habit is probably genetically controlled. Cucurbita plants with bushy growth habit have monogenic inheritance in which the bush genotype is dominant $(B u)$ to vine genotype $(b u)$ and is expressed in early stages of development [11]. Bush-type Cucurbita plants have fewer lateral shoots than vine plants [5], which was the case in the diversity of stem branching reported among Cucurbita landraces of northern KwaZulu-Natal.

Leaf colour varied from uniformly green to green with silvery-white mottling in the axils of the leaf veins. This variation could be attributed to genetic differences among Cucurbita landraces. A range from light to dark green leaf colour exists among $C$. moschata accessions [20]. The silvery-white mottling in the axils of leaf veins among accessions of $C$. maxima, $C$. moschata and $C$. pepo is controlled by a single dominant gene, $M$ [21].

Variation from soft to tough prickly spines or hairs on both stems and leaves of Cucurbita landraces of northern KwaZulu-Natal concurs with the findings of Ndoro et al. [12] in Cucurbita landraces of Zimbabwe. The absence of trichomes in some $C$. maxima leaves is caused by a recessive allele, $g l$ [21]. Also, the foliage of $C$. pepo is ordinarily harshly spiculate, due to stiff, spiny trichomes. However, spinelessness which sometimes occurs in this species is conferred by single recessive genes, spn [21].

High diversity in fruit shape, size and colour among Cucurbita landraces of northern KwaZulu-Natal concurs with the diversity among Cucurbita landraces from Nigeria [10] and C. maxima populations of Turkey [9]. This significant variation is probably an indication of high polygenic fruit characteristics that almost defy simple Mendelian analysis in Cucurbita species [21]. Two genes affect fruit shape: in $C$. pepo, $D i$ controls disc versus pyriform or spherical shape, whereas in C. moschata, Bn controls butternut (bell) shape, as opposed to the elongated crookneck shape of the homozygous recessive [21]. The dark green colour of mature fruits in iNhlwathi emnyama landrace as well as the change of fruit colour from light green to pure yellow or orange before maturity in iPhuzi landrace are probably genetically controlled [21, 22].

The internal part of fruits of Cucurbita landraces in northern KwaZulu-Natal ranged from hollow through intermediate to completely filled. The completely filled fruits of $C$. argyrosperma (isiPhama landrace) and $C$. maxima (uMpampini oluhlaza landrace) landraces concurs with the completely filled $C$. maxima fruits studied in Argentina [22].

In the present study seed shape varied from flat to ovoid and bulged seeds among $C$. argyrosperma, $C$. maxima and $C$. pepo landraces. However, Aruah et al. [10] reported only flat seeds among C. maxima, C. moschata and C. pepo landraces. Balkaya et al. [16] reported a range from wide elliptic through elliptic to narrow elliptic seeds among $C$. maxima populations.

Seed colour ranged from cream or light brown (C. maxima and $C$. pepo landraces) to white (C. argyrosperma landrace). In Nigeria, seed colour ranged from brown through light brown (C. maxima and C. moschata) to white (C. pepo) [10]. Also, in Turkey it varied from white through brown to tawny, among seeds of $C$. maxima populations [16].

The close relationship between $C$. argyrosperma (isiPhama) and C. maxima (uMpampini oluhlaza) landraces in their stem branching habit, leaf colour, and fruit internal hollowness was probably because they both belong to a Cucurbita pepo group. This group has four species (C. pepo, C. moschata, C. maxima and C. argyrosperma) which are related and cross compatible [10], which could have been the case with the isiPhama and uMpampini oluhlaza landraces of northern KwaZulu-Natal.

The uMpampini ophuzi landrace had distinct qualitative features of both $C$. maxima and $C$. pepo species. This was probably influenced by intercropping these Cucurbita landraces, which resulted in gene flow at pollination. The resulting hybrid progeny with mixed genome that was expressed phenotypically and was then maintained for many years by local farmers until established. According to Montes-Hernandez and Eguiarte [23] morphological variation among fruits and seeds of $C$. argyrosperma, $C$. 
moschata, and C. pepo suggests introgression. The allozyme analysis confirmed introgression among these species and revealed the existence of hybrid progeny from a cross between C. argyrosperma and C. pepo; and C. argyrosperma and $C$. moschata. Among the Cucurbita species, $C$. argyrosperma is clearly the most related to $C$. moschata which is the evidence of the gene flow between these inter-planted and naturally open-pollinated species [24]. Aruah et al. [10] reported that Cucurbita species are reproductively isolated from each other by genetic barriers and are therefore identified using morphological characters; thus might be the case with uMpampini ophuzi landrace.

The consumption of shoot apices, fruits, flowers and seeds of Cucurbita landraces agrees with the earlier reports by Jansen van Rensburg et al. [2] and Vorster et al. [25]. However, communities of Mpumalanga and Limpopo provinces of South Africa consume mature leaves, but in northern KwaZulu-Natal they eat shoot apices.

The bitterness of mature leafy shoots in uMpampini oluhlaza landraces might result from the dominance of anti-herbivorous tetracyclic terpenoid called cucurbitacin, which is genetically controlled. The dominant $\mathrm{Cu}$ and recessive $c u$ alleles are responsible for high and low contents of cucurbitacin in cucurbits, respectively [21,26].

Communities of northern KwaZulu-Natal preferred isiPhama, uMpampini oluhlaza and uMpampini ophuzi landraces based on the taste and texture of their cooked fruits. Taste preference of Cucurbita cultivars concurs with the report by Gajewski et al. [27]. Although these landraces were the most preferred ones, their poor fruit yield requires studies that will improve fruit yield for large scale farming.

\section{Conclusion}

Seven distinct Cucurbita landraces, which varied mainly on their vegetative and reproductive features, were identified. These variations, after confirmed with genetic analysis, might form basis for future breeding of such income-promising and hunger alleviating landraces. Assessment of genetic variation among these landraces is necessary to add on documented Cucurbita germplasm in South Africa. This work reported for the first time the existence of Cucurbita argyrosperma in this country. Further studies are necessary to maximize growth and yield of $C$. argyrosperma (isiPhama), C. maxima (uMpampini oluhlaza) and C. maxima/pepo (uMpampini ophuzi) landraces which are the most preferred landraces.

\section{Acknowledgements}

We thank the communities of northern KwaZulu-Natal for sharing their valuable information with us. This study was financially supported by National Research Foundation and the University of Zululand.

\section{REFERENCES}

[1] Hadia, H.A., H.S. Abdel-Razzak and E.E. Hafez. 2008. Assessment of genetic relationships among and within Cucurbita species using RAPD and ISSR markers. Journal of Applied Sciences Research 4(5):515-525.

[2] Jansen van Rensburg, W.S., W. van Averbeke, R. Slabbert, M. Faber, P. van Jaarsveld, I. van Heerden, F. Wenhold and A. Oelofse. 2007a. African leafy vegetables in South Africa. Water SA 33(3):317-326.

[3] Wu, J., Z. Chang, Q. Wu, H. Zhan and S. Xie. 2011. Molecular diversity of Chinese Cucurbita moschata germplasm collections detected by AFLP markers. Scientia Horticulturae 128:7-13.

[4] Dos Santos, M.H., R. Rodrigues, L.S.A. Gonçalves, C.P. Sudré and M.G. Pereira. 2012. Agrobiodiversity in Cucurbita spp. landraces collected in Rio de Janeiro assessed by molecular markers. Crop Breeding and Applied Biotechnology 12:96-103.

[5] Wu, T., J. Zhou, Y. Zhang and J. Cao. 2007. Characterization and inheritance of a bush-type in tropical pumpkin (Cucurbita moschata Duchesne). Scientia Horticulturae 114:1-4.

[6] Faber, M., A. Oelofse, P.J. van Jaarsveld, F.A.M. Wenhold and W.S. Jansen van Rensburg. 2010. African leafy vegetables consumed by households in the Limpopo and KwaZulu-Natal Provinces in South Africa. South African Journal of Clinical Nutrition 23(1):30-38.

[7] Mujaju, C., J. Sehic, G. Werlemark, L. Garkava-Gustavsson, M. Fatih and H. Nybom. 2010. Genetic diversity in watermelon (Citrullus lanatus) landraces from Zimbabwe revealed by RAPD and SSR markers. Hereditas 147:142-153.

[8] Modi, A.T. 2004. Short-term preservation of maize landrace seed and taro propagules using indigenous storage methods. South African Journal of Botany 70(1):16-23.

[9] Balkaya, A., M. Özbakir and E.S. Kurtar. 2010. The phenotypic diversity and fruit charaterization of winter squash (Cucurbita maxima) populations from the Black Sea Region of Turkey. African Journal of Biotechnology 9(2):152-162.

[10] Aruah, C.B., M.I. Uguru and B.C. Oyiga. 2010. Variation among some Nigerian Cucurbita landraces. African Journal of Plant Science 4(10):374-386.

[11] Wu, T. and J. Cao. 2008. Differential gene expression of tropical pumpkin (Cucurbita moschata Duchesne) bush mutant during internode development. Scientia Horticulturae 117:219-224.

[12] Ndoro, O.F., R.M. Madakadze, S. Kageler and A.B. Mashangaidze. 2007. Indigenous knowledge of the traditional vegetable pumpkin (Cucurbita maxima/moschata) from Zimbabwe. African Journal of Agricultural Research 2(12):649-655.

[13] Jansen van Rensburg, W., I.H.J. Voster, J.J.B. Van Zijl and S.L. Venter. 2007b. Conservation of African Leafy Vegetables in South Africa. African Journal of Food, Agriculture, Nutrition and Development 7(4). 
[14] Fish, L. 1999. Preparing herbarium specimens. Strelitzia 7. National Botanical Institute. Pretoria, South Africa.

[15] Ahamed, K.U., B. Akhter, M.R. Islam, N. Ara and M.R. Humauan. 2011. An assessment of morphology and yield characteristics of pumpkin (Cucurbita moschata) genotypes in northern Bangladesh. Tropical Agricultural Research and Extension 14(1):07-11.

[16] Balkaya, A., R. Yanmaz and M. Özbakir. 2009. Evaluation of variation in seed characters of Turkish winter squash (Cucurbita maxima) populations. New Zeal. J. Crop Hort. 37(3):167-168

[17] Lewu, F.B. and S. Mavengahama. 2010. Wild vegetables in Northern KwaZulu-Natal, South Africa: Current status of production and research needs. Scientific Research and Essays 5(20):3044-3048.

[18] Molebatsi, L.Y., S.J. Siebert, S.S. Cilliers, C.S. Lubbe and E. Davoren. 2010. The Tswana Tshimo: A homegarden system of useful plants with a particular layout and function. African Journal of Agricultural Research 5(21):2952-2963.

[19] Kasrawi, M.A. 1995. Diversity in landraces of summer squash from Jordan. Genetic Resources of Crop Evolution 42:223230.

[20] Du, X., Y. Sun, X. Li, J. Zhou and X. Li. 2011. Genetic divergence among inbred lines in Cucurbita moschata from China. Scientia Horticulturae 127:207-213.

[21] Paris, H.S. and R.N. Brown. 2005. The genes of pumpkin squash. HortScience 40(6):1620-1630.

[22] López-Anido, F., V. Cravero, P. Asprelli, E. Cointry, I. Firpo and S.M. García. 2003. Inheritance of immature fruit colour in Cucurbita maxima var. Zapallito (Carrière) Millán. Cucurbit Genetic Cooperative Report 26:48-50.

[23] Montes-Hernandez, S. and L.E. Eguiarte. 2002. Genetic structure and indirect estimates of gene flow in three taxa of Cucurbita (Cucurbitaceae) in western Mexico. American Journal of Botany 89(7):1156-1163.

[24] Cuevas-Marrero, H. and L. Wessel-Beaver. 2008. Morphological and RAPD marker evidence of gene flow in open-pollinated populations of Cucurbita moschata interplanted with C. argyrosperma. Cucurbitaceae 2008, Proceedings of the IXth EUCARPIA Meeting on Genetics and Breeding of Cucurbitaceae (Pitrat $\mathrm{M}$, ed), INRA, Avignon (France), May 21-24th: pp 347-352.

[25] Vorster, I.H.J., W. Jansen van Rensburg, J.J.B. Van Zijl and S.L. Venter. 2007. The importance of traditional leafy vegetables in South Africa. African Journal of Food, Agriculture, Nutrition and Development 7(4):1-13.

[26] Bisognin, D.A. 2002. Origin and evolution of cultivated cucurbits. Ciência Rural 32(5):715-723.

[27] Gajewski, M., J. Radzanowska, H. Danilcenko, E. Jariene and J. Cerniauskiene. 2008. Quality of pumpkin cultivar in relation to sensory characteristics. Notulae Botanicae Horti Agrobotanici Cluj-Napoca 36(1):73-79. 